\title{
Analisis Kemampuan Dasar Matematika Upaya Meningkatkan Kualitas Mahasiswa Baru FPMIPA
}

\author{
${ }^{1}$ Lutfiyah, ${ }^{2}$ Dwi Noviani Sulisawati, ${ }^{3}$ M. Fadil Djamali \\ 1,2,3Program Studi Pendidikan Matematika, FPMIPA, IKIP PGRI Jember, Indonesia \\ Email:1 1azkalutfimh@gmail.com
}

\begin{abstract}
Analysis of new student registration based on data, that new students of FPMIPA IKIP PGRI Jember in many registration forms dropped first choice in biology education study program and second choice in other faculties, based on that matter is an evaluation material that must be done by FPMIPA whether students new students who choose biology education study programs also have good basic math skills with the aim of improving the quality of new student admissions at FPMIPA, so it needs to be analyzed about the basic mathematical abilities possessed by new students who are in FPMIPA Especially new students of biology education study programs. The formulation of the problem in this case, is how to analyze the basic abilities of mathematics to improve the quality of new students of FPMIPA, with the aim is to find out the results of the analysis of the basic mathematical abilities of new students of FPMIPA to improve the quality of FPMIPA new student admissions each year. Descriptive qualitative research design with 6 research subjects, the results of the study that the structure of solving mathematical problems that are owned by new students of biology education study programs, 4 subjects have basic mathematical abilities. The study concludes that new students of FPMIPA who have an interest in choosing biology education study programs also have basic mathematical abilities, which is an effort to improve the quality of new student admissions at FPMIPA.
\end{abstract}

Keyword: basic mathematics ability, improving quality, new students of FPMIPA

\begin{abstract}
Abstrak: Analisa pendaftaran mahasiswa baru berdasarkan data, bahwa mahasiswa baru FPMIPA IKIP PGRI Jember dalam formulir pendaftaran banyak yang menjatuhkan pilihan pertama pada program studi pendidikan biologi dan pilihan kedua pada fakultas yang lain, berdasarkan hal tersebut merupakan bahan evaluasi yang harus dilakukan oleh FPMIP Apakah mahasiswa baru yang memilih program studi pendidikan biologi juga memiliki kemampuan matematika dasar yang baik dengan tujuan meningkatkan kualitas penerimaan mahasiswa baru di FPMIPA, sehingga perlu dianalisa tentang kemampuan dasar matematika yang dimiliki oleh mahasiswa baru yang berada di FPMIPA Khususnya mahasiswa baru program studi pendidikan biologi. Perumusan masalah dalam hal ini bagaimanakah analisiskemampuan dasar matematika dalam upaya meningkatkan kualitas mahasiswa baru FPMIPA, dengan tujuan untuk mengetahui hasil analisa kemampuan dasar matematika yang dimiliki mahasiswa baru FPMIPA dalam upaya meningkatkan kualitas penerimaan mahasiswa baru FPMIPA setiap tahunnya.Desain penelitian deskriptif kualitatif dengan 6 subjek penelitian, hasil penelitian bahwa struktur penyelesaian soal matematika yang dimiliki oleh mahasiswa baru program studi pendidikan biologi terdapat 4 subjek yang memiliki kemampuan dasar matematika.Simpulan penelitian bahwa mahasiswa baru FPMIPAyang mempunyai minat memilih program studi pendidikan biologi juga memiliki kemampuan dasar matematikahal tersebut merupakan upaya peningkatan kualitas penerimaan mahasiswa baru pada FPMIPA.
\end{abstract}

Kata Kunci: kemampuan dasar matematika, meningkatkan kualitas, mahasiswa baru FPMIPA 


\section{PENDAHULUAN}

Pendidikan memiliki peranan penting dalam meningkatkan sumber daya manusia pada suatu Negara dalam menghadapi perkembangan zaman yang semakin meningkat pesat, pendidikan pada suatu Negara memiliki dampak kemajuan dari Negara tersebut, hal itulah dapat mendorong pemerintah Indonesia untuk melakukan perubahan, dimulai dari kurikulum sehingga pada perubahan kewajiban bagi seluruh warga Negara Indonesia untuk melaksanakan wajib belajar 12 tahun.Salah satu pelajaran yang diwajibkan harus ada disekolah pada pendidikan dan pengajaran 12 tahun yaitu pelajaran matematika, karena matematika dapat dikatakan sebagai dasar dari berbagai ilmu pengetahuan serta selalu dibutuhkan dalam kehidupan sehari-hari.Pelajaran matematika merupakan pengetahuan yang melatih siswa berpikir logis serta kritis dan memiliki analisa yang baik. Menurut Johnson dan Rising dalam Sandewita (2015) mengatakan bahwa matematika merupakan pengetahuan terstruktur, dimana teori serta sifat dibuat dengan cara deduktif sesuai unsur yang didefinisikan atau unsur yang tidak didefinisikan dengan berdasarkan aksioma, teori dan sifat yang sudah bisa dibuktikan kebenarannya.

Selama ini siswa menganggap bahwa matematika merupakan pelajaran yang sulit serta membentuk kesan dan pengalaman secara negatif pada pelajaran matematika sehingga pada umumnya berdampak buruk terhadap motivasi siswa dalam belajar matematika serta berdampak pada penyesuaian akademik disekolah.Gurganus dalam Siregar (2017) berpendapat bahwa pengalaman siswa sebelumnya terhadap matematika merupakan prediktor yang kuat sekali pada kesuksesan dimasa mendatang. Sehingga sikap positif siswa pada matematika yang terbentuk dari awal akan menjadikan faktor penting dalam kesuksesan belajar matematika yang dianggap sulit oleh siswa. Kecemasan matematika bisa diperparah oleh kondisi pembelajaran didalam kelas yang kurang menyenangkan bagi siswa, faktor tersebut bisa muncul berasal dari desain pembelajaran yang monoton selain itu guru matematika kurang cakap dalam menyampaikan pelajaran didalam kelas (Anita, 2014). Marpaung dalam Widyawati (2016) mengatakan bahwa pendidikan matematika yang terjadi pada kita selama ini belum berhasil dalam meningkatkan pemahaman yang baik pada siswa, melainkan membuat perasaan takut pada siswa, persepsi siswa pada matematika merupakan pelajaran yang sukar dikuasai, matematika dianggap tidak bermakna, pelajaran yang membosankan, dan juga penyebab stress.Pernyataan tersebut mengindikasikan sebagian besar siswa pada pelajaran matematika belum bisa merubah ranah afektif siswa serta ranah kognitif siswa menjadi lebih baik.

Disekolah diajarkan pelajaran matematika sekolah dengan tujuan mempersiapkan siswa agar bisa menggunakan matematika serta pola pikir matematika pada kehidupan sehari-hari serta dapat digunakan dalam mempelajari ilmu pengetahuan yang lainnya (Amir, 2013).oleh sebab itu belajar dimulai dari proses ingin mengetahui, ketika seseorang memiliki masalah dan mau menyelesaikannya, maka orang tersebut akan menggunakan pikirannya untuk meninjau fakta-fakta apapun yang ada disekitarnya yang ada hubungannya dengan masalah tersebut, lalu seseorang tersebut akan menghubungkan fakta-fakta yang ada untuk mencari alternatif penyelesaiannya seperti yang diinginkan (Suherman, 2015). Kecerdasan merupakan kemampuan seseorang menyelesaikan masalah yang dihadapi serta mencari dan memecahkan masalah dengan mencari jalan keluarnya sampai masalah tersebut dinyatakan selesai dengan cara menggunakan potensi yang dimiliki (Irvaniyah, 2014).

Kecerdasan siswa untuk memecahkan masalah dengan menggunakan potensi yang dimiliki didasari dengan pengetahuan dasar yang kuat sebelumnya.Menurut Kendeou \&Broek dalam Firmansyah (2017) dalam memahami bahan pelajaran siswa dipengaruhi oleh kemampuan awal yang sudah dimiliki.Mutu pembelajaran yang 
dialami siswa sebelumnya dipengaruhi dengan Pembentukan kemampuan awal.Apabila pembelajaran sebelumnya tidak efektif, maka hasil belajarnya tidak sesuai dengan tujuan yang telah ditetapkan. Apabila hal tersebut terjadi, maka dalam memahami materi berikutnya akan mengalami kesulitan bagi siswa karena pengetahuan yang dimilikinya pada tingkat yang rendah dari materi sebelumnya yang juga merupakan materi prasyarat untuk materi selanjutnya.Menurut Caillies dalam Firmansyah (2017) banyak siswa dalam memahami pelajaran bergantung pada kemampuan awal yang menyediakan ingatan untuk siswa dalam menemukan informasi yang mereka butuhkan dan kapan mereka butuhkan.Kemampuan awal dianggap akumulasi kepandaian yang dimiliki pada awal materi pembelajaran yang dapat digunakan kapan dan dimana secara tepat.

Siswa disekolah diberikan pengetahuan awal sebagai bekal yang akan digunakan pada jenjang berikutnya, dimana pengetahuan sebelumnya yang mereka miliki sebagai kemampuan dasar yang dimiliki oleh masing-masing individu siswa.Kemampuan dasar merupakan suatu persiapan yang harus dimiliki siswa untuk memudahkan memahami dan menguasi materi selanjutnya, pengetahuan dasar yang dimiliki siswa merupakan hal terpenting untuk diri siswa dalam mengkonstruksi pengetahuan yang dimilikinya dengan hasil belajar yang diperoleh, kondisi seperti itu juga diperlukan oleh perguruan tinggi untuk menjadi bahan penerimaan mahasiswa baru, bahwa mahasiswa yang diterima memiliki kemampuan dasar yang akan menjadikan jembatan bagi diri mereka untuk mendalami materi kuliah selanjutnya. Sebab materi kuliah semakin rumit yang harus dipahami daripada materi sekolah, sebab perguruan tinggi merupakan jenjang pendidikan tinggi dimanamahasiswa yang diterima harus memiliki kemampuan dasar yang memadai agar proses pembelajaran selanjutnya dapat berjalan sesuai dengan target program studi dalam perguruan tinggi tersebut.

Oleh sebab itu, pada perguruan tinggi kami melakukan seleksi masuk perguruan tinggi untuk menjaga kualitas penerimaan mahasiswa baru FPMIPA, tetapi berdasarkan analisa pendaftaran mahasiswa baru berdasarkan data, bahwa mahasiswa baru FPMIPA IKIP PGRI Jember dalam formulir pendaftaran banyak yang menjatuhkan pilihan pertama pada program studi pendidikan biologi dan pilihan kedua pada fakultas yang lain, melainkan bukan pada salah satu program studi lain yang berada di FPMIPA, hal tersebut merupakan bahan evaluasi yang harus dilakukan oleh FPMIPA,sebab fakultas kami memiliki dua program studi yang seharusnya jika pilihan pertama ada di FPMIPA begitu juga pada pilihan kedua, dari permasalahan diatas bagaimanakah kemampuan dasar matematika yang dimiliki oleh mahasiswa baru FPMIPA yang memilih program studi pendidikan biologi, dengan mangacu pada pentingnya kemampuan dasar matematika yang harus dimiliki oleh mahasiswa FPMIPA, sebab matematika merupakan pengetahuan utama untuk mempelajari pengetahuan yang lain. Tujuan tersebut dilakukan untuk meningkatkan kualitas penerimaan mahasiswa baru di FPMIPA, sehingga perlu dianalisa tentang kemampuan dasar matematika yang dimiliki oleh mahasiswa baru yang berada di FPMIPA Khususnya mahasiswa baru program studi pendidikan biologi.Perumusan masalah dalam hal ini bagaimanakah analisis kemampuan dasar matematika dalam upaya meningkatkan kualitas mahasiswa baru FPMIPA, dengan tujuan untuk mengetahui hasil analisa kemampuan dasar matematika yang dimiliki mahasiswa baru FPMIPA dalam upaya meningkatkan kualitas penerimaan mahasiswa baru FPMIPA setiap tahunnya.

\section{METODE}

Desain penelitian yang digunakan deskriptif kualitatif, analisa deskripsi terhadap konsep dasar yang dimiliki mahasiswa program studi pendidikan biologi terkait dengan matematika dasar yang pernah mereka dapatkan di jenjang SMA atau sederajat.Waktu penelitian pada semester gasal, tempat penelitian FPMIPA IKIP PGRI Jember.Subjek 
penelitian yaitu mahasiswa baru FPMIPA program studi pendidikan biologi. Subjek diambil secara acak sejumlah 3 mahasiswa sebanyak 2 tahap dengan mahasiswa yang berbeda total jumlah subjek penelitian sebanyak 6 mahasiswa, terlihat pada table berikut ini.

Tabel 1. Pengkodean Subjek Penelitian

\begin{tabular}{cll}
\hline Tahap Acak & Subjek Penelitian & Kode \\
\hline \multirow{2}{*}{ I } & Subjek 1 & S1 \\
& Subjek 2 & S2 \\
& Subjek 3 & S3 \\
\hline \multirow{2}{*}{ II } & Subjek 4 & S4 \\
& Subjek 5 & S5 \\
& Subjek 6 & S6 \\
\hline
\end{tabular}

Berikut ini penyajian struktur dalam penyelesaian soal yang diberikan kepada subjek penelitian

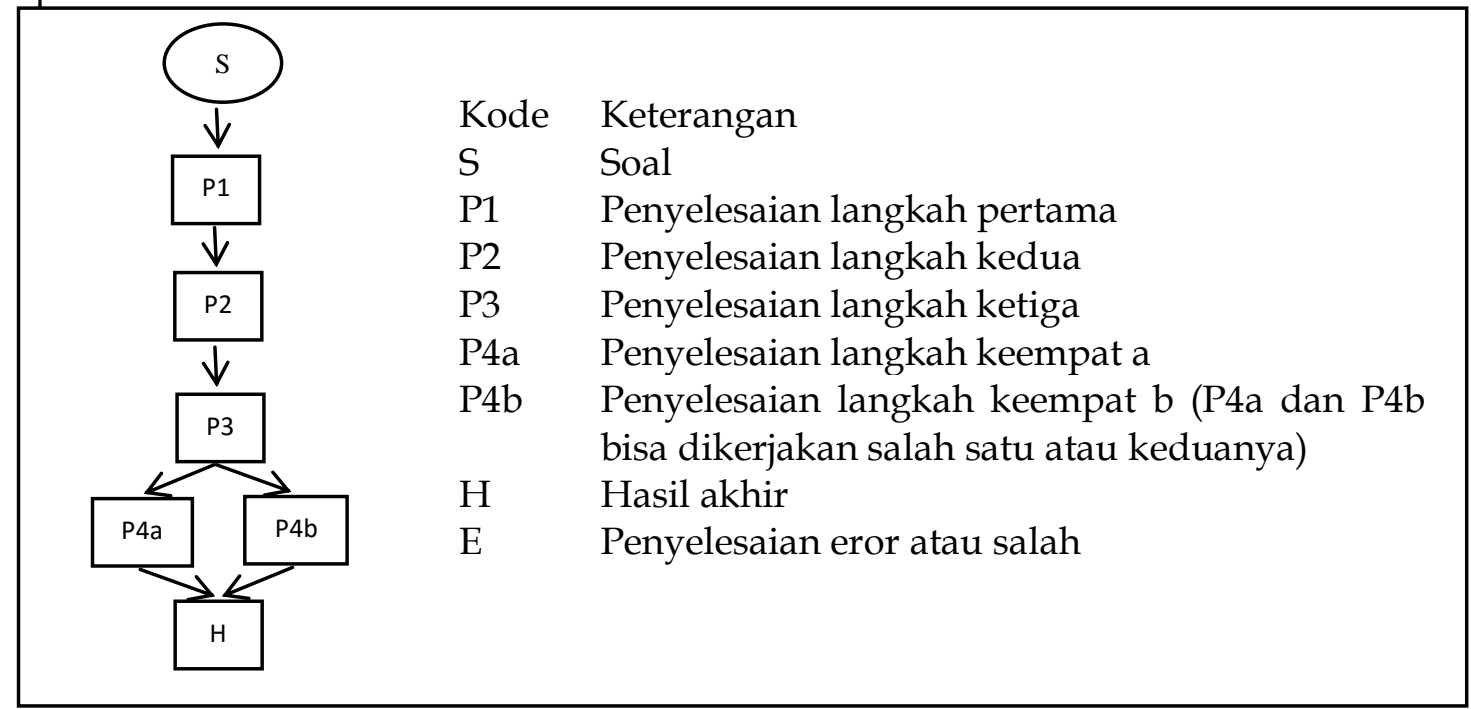

\section{Gambar 1. Struktur Penyelesaian Soal}

Instrument dalam penelitian ini berupa soal tes dan lembar wawancara. Teknik pengumpulan data dengan memberikan tes kemampuan dasar matematika yang diberikan pada mahasiswa baru FPMIPA program studi pendidikan biologi yang menempuh matakuliah matematika dasaryang dilakukan pada awal pertemuan sebelum kontrak perkuliahan, sedangkan wawancara dilakukan setelah subjek penelitian mengumpulkan lembar jawabannya, wawancara dilakukan pada mahasiswa secara bergantian dengan cara memanggil satu persatupada keenam subjek penelitian yang dilakukan secara berurutan, pertanyaan dalam wawancara terkait pada lembar jawaban yang dihasilkan oleh masing-masing mahasiswa.Teknik analisa data yaitu deskriptif kualitatif dengan mengklasifikasikan objek-objek penelitian untuk dapat menentukan masing-masing kategori berdasarkan data-data deskriptif yang telah didapatkan.Dengan langkah-langkah seperti dalam gambar berikut ini. 


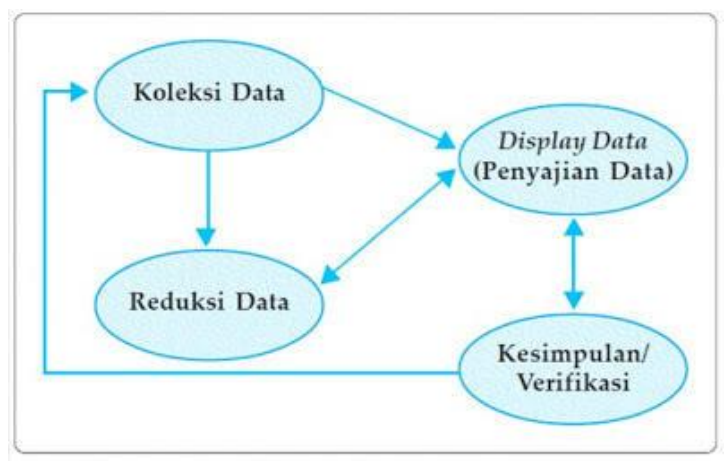

\section{Gambar 2. Desain Penelitian Deskriptif Kualitatif}

\section{HASIL DAN PEMBAHASAN}

Berdasarkan permasalahan diatas, sebelum menganalisa kemampuan dasar matematika yang dimiliki oleh mahasiswa FPMIPA, peneliti melakukan wawancara awal terhadap mahasiswa baru program studi pendidikan biologi, dengan tujuan untuk mengetahui alasan masing-masing mahasiswa dengan pemilihan program studi. Hasil wawancara awal dengan beberapa mahasiswa program studi pendidikan biologi dapat disimpulkan bahwa beberapa mahasiswa menyatakan keinginannya kuliah di FPMIPA yaitu pada program studi pendidikan biologi, tetapi untuk program studi pendidikan matematika mereka memiliki beberapa alasan diantaranya mahasiswa merasa takut dengan matematika selain itu mahasiswa merasa kesulitan belajar matematika danada juga menyatakan bahwa belajar matematika itu menjenuhkan dan juga membosankan sebab materinya hanya menghitung. Dengan beberapa alasan diatas, peneliti yang juga merupakan pengampu matakuliah matematika dasar yang berada pada semester 1 pada program studi pendidikan biologi memiliki tujuan untuk mengetahui kemampuan dasar matematika yang dimiliki oleh mahasiswa program studi pendidikan biologi terkait upaya peningkatan kualitas mahasiswa baru FPMIPA, hasil penelitian ini sebagai salah satu bahan pertimbangan yang dapat diberikan kepada pihak FPMIPA.

Untuk mengetahui kemampuan dasar matematika pada mahasiswa program studi pendidikan biologi peneliti memberikan tes pada mahasiswa saat pertemuan pertama matakuliah matematika dasar sebelum kontrak perkulihan selanjutnya. Hasil tes akan diambil dari 6 mahasiswa dengan cara 2 tahap pengambilnya, tahap 1 diambil 3 subjek lalu kita simpulkan hasil analisanya, setelah itu kita ambil 3 subjek lagi pada tahap 2 lalu disimpulkan, hasil kesimpulan tahap 1 dan tahap 2 kita bandingkan lalu mengambil kesimpulan akhir. Beberapa hasil analisa dari lembar jawaban subjek penelitian kami paparkan dibawah ini

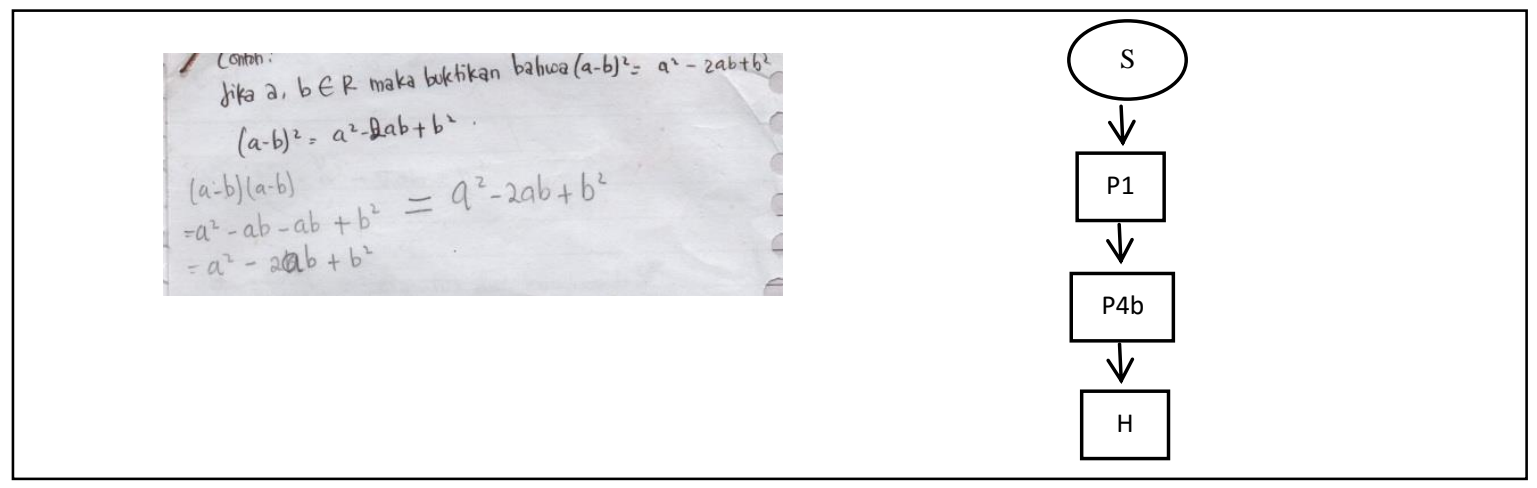

Gambar 3. Hasil Kerja Subjek 1 (S1) dan Struktur Penyelesaian Soal 
Hasil penyelesaian S1 dalam menjawab soal tes terlihat dari struktur penyelesaiannya bahwa S1 mampu menyelesaikan soal tes tersebut, walaupun melewati langkah penyelesaian P2 dan P3.Hasil wawancara yang diperoleh oleh peneliti terhadap penyelesaian pada lembar jawaban yang dimiliki oleh S1,dimana S1 mengatakan untuk menyelesaikan $(a-b)^{2}$ dengan cara dikalikan yaitu $(a-b)$ sebanyak dua kali seperti $(a-b)(a-b)$ lalu tinggal mengalikan silang seperti yang dijelaskan oleh guru saya saat di SMA, karena penyelesaian akhir S1 benar maka peneliti menanyakan terkait hukum assosiatif, ternyata S1 menyatakan tahu terhadap hukum assosiatif.

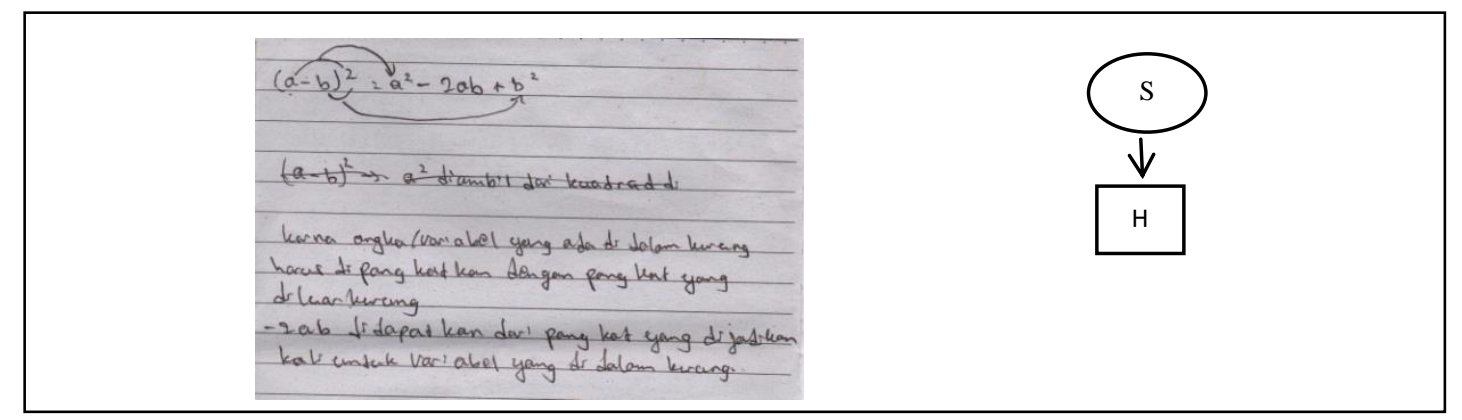

Gambar 4. Hasil Kerja Subjek 2 (S2) dan Struktur Penyelesaian Soal

Hasil penyelesaian S2 dalam mengerjakan soal tes yang dibeikan terlihat dari struktur penyelesaiannya bahwa S2 masih ada kebingungan, penyelesaian soal yang dilakukan oleh S2 belum bisa menemukan sesuai perintah soal melainkan pada lembar jawaban berupa penjelasan, dimana dalam penjelasan tersebut S2 belum bisa membedakan antara angka dan variable, selain itu S2 juga menjelaskan bahwa (-2ab) diperoleh dari perkalian antara pangkat dan variable yang ada di dalam kurung.

Hasil wawancara yang diperoleh dari S2 menyatakan bahwa a didalam kurungdipangkatkan 2 lalu jadi $\mathrm{a}^{2}$ setelah itu b didalam kurung dipangkatkan 2 lalu jadi $\mathrm{b}^{2}$ untuk -2ab didapatkan dari pangkat yang dijadikan kali dengan a dan $\mathrm{b}$ yang berada didalam kurung, karena pada lembar jawaban S2 tidak dituliskan penyelesaiannya maka peneliti memberikan pertanyaan berikutnya tentang tanda negatif (pengurangan) dan tanda positif (penjumlahan) yang terletak pada $a^{2}-2 a b+b^{2}$ ternyata S2 mengatakan tidak tahu caranya, lalu S2 balik bertanya pada peneliti apakah saat menyelesaikan $(a-b)^{2}$ tanda harus negatif dan positif seperti $a^{2}-2 a b+b^{2}$ apakah tandanya tidak negatif semua seperti pada $(a-b)^{2}$ dari pertanyaan S2 tersebut peneliti melihat ada kebingungan pada S2 saat mengerjakan soal sehingga tidak bisa menuliskan penyelesainnya, dari pertanyaan yang diutarakan S2 peneliti tidak langsung menjawab penyelesaiannya agar S2 mampu mengingat kembali materi sekolah, maka peneliti memberikan pertanyaan lebih lanjut yaitu apakah S2 pernah mendengar dan mengetahui hukum assosiatif saat disekolah dulu, ternyata S2 mengatakan mengetahuinya.

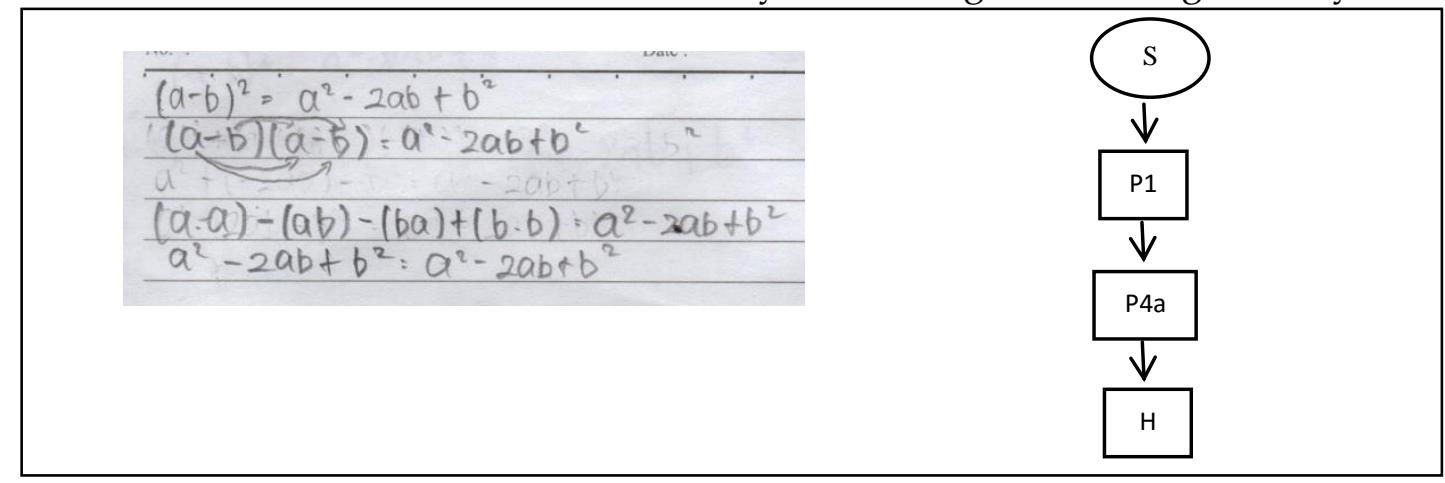

Gambar 5. Hasil Kerja Subjek 3 (S3) dan Struktur Penyelesaian Soal 
Hasil penyelesaian S3 dalam mengerjakan soal tes ternyata S3 memiliki cara yang sama dengan S1 bedanya kalau S1 menggunakan P4b sedangkang S3 menggunkan P4a, selain itu S3 menuliskan hasil penyelesaian lebih rinci dalam perkaliannya.

Hasil wawancara yang diperoleh dari S3 mengatakan bahwa cara menyelesaikan soal tersebut mengikuti cara guru saat disekolah dulu yaitu $(a-b)^{2}$ ditulis (a-b) (a-b) lalu dikalikansilang sehingga hasilnya saya tulis (a.a) lalu (a.b) setelah itu (b.a) baru yang terakhir (b.b) setelah dikalikan semua baru digabung yang sama antara (a.b) dengan (b.a) barulah dapat diketahui hasilnya, dengan rincian pada $\mathrm{P} 4 \mathrm{a}$, peneliti mengutarakan pertanyaan apakah (a.b) sama (b.a) dapat digabung sehingga hasilnya (-2ab) ternyata S3 menjawab bisa, sebab (a.b) dan (b.a) sama saja karena keduanya negatif maka hasilnya (2ab) lalu peneliti melanjutkan bertanya tentang hukum assosiatif, jawaban S3 mengetahui.

Hasil analisa dari ketiga subjek penelitian diatas bahwa S1dan S3 dapat menyelesaikan soal tes dengan baik dan benar berdasarkan hasil wawancara S1 dan S3 kedua subjek tersebut memahamidalam menyelesaian soal walaupun S1 dan S3 tidak menggunakan konsep dari hukum assosiatif, sedangkan S2 seballiknya belum bisa menyelesaikan soal dengan baik tetapi berdasarkan hasil wawancara ketiga subjek penelitian yaitu S1, S2 dan S3 mengetahui hukum assosiatif maka pada tahap I ini peneliti menyatakan bahwa dua subjek penelitian memiliki kemampuan dasar matematika sedangkan satu subjek belum memiliki kemampuan dasar matematika.

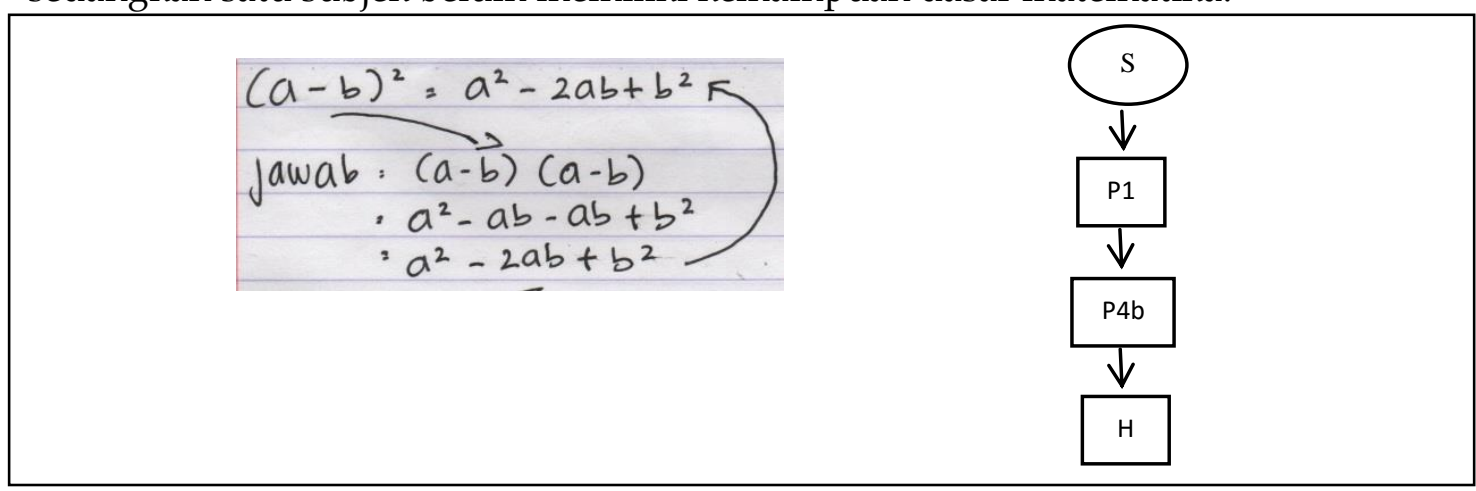

\section{Gambar 6. Hasil Kerja Subjek 4 (S4) dan Struktur Penyelesaian Soal}

Hasil penyelesaian soal yang dimiliki oleh S4 terlihat dari struktur penyelesaiannya sama seperti S1 dan Juga S3 sehingga S4 juga bisa dinyatakan sangat memahami perintah soal selain itu S4 juga mampu menuliskan penyelesaian dengan rapi.

Hasil wawancara yang diperoleh dari S4 mengatakan bahwa $(a-b)^{2}$ artinya (a-b) $(a-b)$ baru setelah itu dikalikan secara bergantian dari masing-masing a dan b pada kurung yang depan dengan a dan $b$ pada kurung yang belakang baru didapatkan $a^{2}-a b-a b+b^{2}$ dimana ab yang kedua itu sebenarnya ba karena sama saja maka langsung ditulis ab biar sama seperti yang didepannya agar lebih mudah untuk menggabungkan dan memahami sehingga mudah menyederhanakan untuk memperoleh $a^{2}-2 a b+b^{2}$ setelah itu peneliti memberikan pertanyaan berikutnya apakah S4 mengetahui hukum assosiatif, ternyata S4 menjawab tahu lalu peneliti melanjutkan pertanyaan berikutnya apakah S4 mengetahui bahwa soal tersebut bisa diselesaikan dengan hukum assosiatif, S4 mengatakan belum mengetahui sebab disekolah dulu hanya diberitahu dengan cara dikalikan secara bergantian untuk mendapatkan hasilnya. 


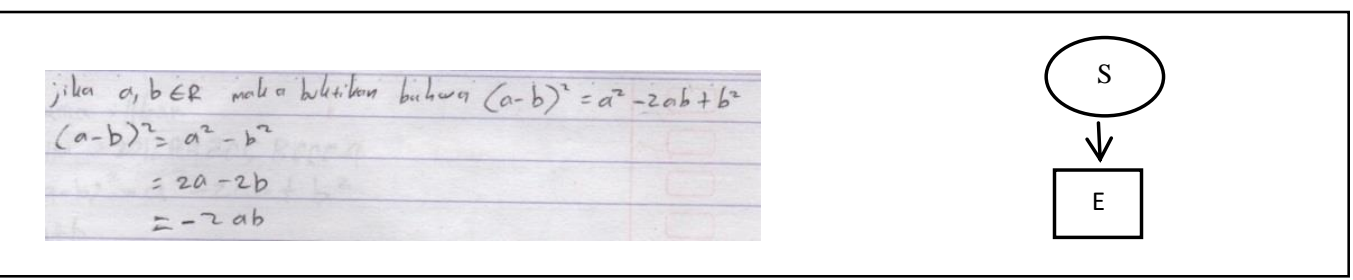

Gambar 7. Hasil Kerja Subjek 5 (S5) dan Struktur Penyelesaian Soal

Hasil penyelesaian S5 dalam mengerjakan soal berdasarkan struktur penyelesaian diatas bahwa S5 belum mampu memahami soal sehingga penyelesaian yang diperoleh tidak sesuai perintah soal, S5 memiliki penyelesaian tetapi belum tepat.

Hasil wawancara yang diperoleh dari S5 mengatakan bahwa $(a-b)^{2}$ sama dengan $a^{2}-b^{2}$ dimana a dan $b$ yang ada didalam kurung sama-sama dipangkatkan 2 , lalu menjadi $2 a-2 b$ setelah itu karena ada negatif maka hasilnya -2ab. Peneliti melanjutkan bertanya pada S5 untuk penyelesaian E sehingga hasilnya $2 a-2 b$ diperoleh dari mana, S5 terdiam beberapa saat sampai peneliti mengulangi lagi pertanyaannya, setelah mengulangi pertanyaan S5 akhirnya menjawab bahwa 2a-2b diperoleh dari perkiraan saja,selanjutnya peneliti menanyakan dengan hasil yang diperoleh pada E selanjutnya kenapa ditemukan -2ab jawaban S5 sebab pada2a-2b ada negatif maka kita tulis dulu negatifnya baru dilanjut menulis 2 dan a serta b sesuai dengan soal, walaupun dari jawabannya S5 tidak bisa menyelesaikan peneliti tetap menanyakan apakah S5 mengetahu hukum assosiatif S5 menjawab tidak tahu.
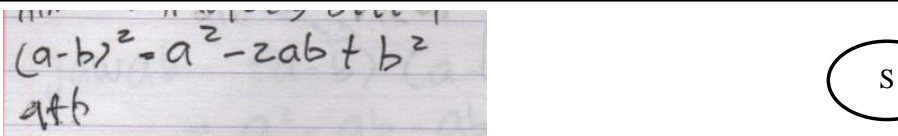

$\mathrm{S}$

Gambar 8. Hasil Kerja Subjek 6 (S6) dan Struktur Penyelesaian Soal

Hasil penyelesaian S6 dalam mengerjakan soal terlihat pada struktur penyelesaiannya bahwa S6 belum mampu memberikan penyelesaian sama sekali atau kata lain tidak ada jawaban yang ditulis melainkan hanya menuliskan $a+b$ dibawah soalnya, disini peneliti tidak pernah tahu dengan maksud penulisan $a+b$ yang dilakukan oleh S6.

Hasil wawancara yang diperoleh dari S6,dimana S6 hanya mengatakan minta maaf karena tidak bisa menyelesaiakan soal yang diberikan disebabkan karena S6 benarbenar tidak memahami perintah soal yang diberikan sehingga S6 mengatakan tidak bisa menuliskan jawabannya, peneliti menanyakan tentang penulisan $a+b$ dibawah soal, ternyata jawaban S6 tidak tahu kenapa menuliskan $a+b$ karena bingung apa yg mau ditulis pada lembar jawaban, sedangkan teman-teman sudah pada mengumpulkan semua, memang saat mengerjakan soal, S6 paling akhir untuk mengumpulkan lembar jawabannya.Walaupun S6 belum mampu memberikan jawaban dari soal tes tetapi peneliti berusaha memberikan pertanyaan berikutnya yaitu apakah S6 mengetahui tentang hukum assosiatif, ternyata jawabannya belum mengetahui.

Dari hasil analisa pada tahap II bahwa S4 dapat menyelesaikan soal dengan baik, tetapi S5 dan S6 merupakan kebalikan dari S4 bahwa keduanya tidak bisa menyelesaikan soal tersebut. Berdasarkan hasil wawancara dari ketiga subjek yang mengetahui hukum assosiatif hanya S4 sedangkan S5 dan S6 belum mengetahuinya, sehingga pada tahap II ini peneliti menyatakan bahwa satu subjek memiliki kemampuan dasar matematika sedangkan dua subjek belum memiliki kemampuan dasar matematika. 
Pada penelitian ini untuk menjawab rumusan permasalahan maka harus membandingan hasil pada tahap I dan tahap II, ternyata kedua tahap tersebut memiliki berbandingan terbalik yaitu pada tahap I yang tidak bisa menyelesaikan soal dengan baik ada 1 subjek dan 2 subjek dapat menyelesaiakan soal dengan baik, sedangkan pada tahap II yang belum bisa menyelesaikan soal ada 2 subjek dan 1 subjek yang bisa menyelesaikan soal dengan baik, oleh sebab itu peneliti perlu menganalisa kembali pada S2,S5 dan juga S6 untuk menjawab perumusan diatas.

Hasil yang peneliti peroleh dari analisa ulang pada S2, S5, dan S6 bahwa dari penyelesaian yang dimiliki oleh S2 dan didukung dengan hasil wawancara S2yang juga mengatakan bahwa S2 mengetahui hukum assosiatif maka bisa anggap bahwa S2 dapat menyelesaikan tetapi tidak bisa menuliskan secara matematika, melaikan hanya bisa menjelaskan dari perintah soal tersebut, sehingga penjelasannya hanya menggunakan cara atau bahasanya sendiri. Sedangkan untuk S5 dan S6 belum bisa menyelesaiakan soal, kedua subjek tersebut memiliki perbedaan dimana S5 masih bisa menuliskan penyelesaiannya walaupun tidak tepat, sedangkan S6 tidak bisa menuliskan penyelesaiannya sama sekali, sehingga hasil analisa ulang peneliti menyatakan bahwa keempat subjek penelitian yaitu S1, S2, S3, S4 memiliki kemampuan dasar matematika sedangkan kedua subjek penelitian yaitu S5 dan S6 belum memiliki kemampuan dasar matematika, maka jawaban dari perumusan masalah dapat dinyatakan bahwa mahasiswa FPMIPA yang mempunyai minat memilih program studi pendidikan biologi juga memiliki kemampuan dasar matematika yang merupakan upaya peningkatan kualitas penerimaan mahasiswa baru di FPMIPA.

Hasil penelitian ini merupakan salah satu bahan pertimbangan FPMIPA dalam mengembangkan program studi yang berada di FPMIPA, sehingga memiliki luaran calon pendidik yang lebih professional dalam profesinya baik sebagai guru matematika maupun guru biologi.Menurut (Dewanti, 2012) Profesional merupakan pekerjaan atau suatu kegiatan yang dilakukan oleh seseorang serta menjadi sumber kehidupan yang perlu keahlian serta kemahiran dan kecakapan yang sesuai standar mutu serta diperlukan pendidikan profesi. Guru merupakan tenaga profesional memiliki arti bahwa pekerjaan seorang guru hanya bisa dilakukan oleh seseorang yang memiliki kualifikasi akademik, kompetensi dan sertifikat pendidik berdasarkan persyaratan pada setiap jenis serta jenjang pendidikan tertentu. Guru tentunya mempunyai beban yang cukup tinggi serta berat dalam mewujudkan pendidikan yang berkualitas. Guru merupakan penentu untuk baik atau tidaknya kualitas pendidikan yang baik secara proses dan hasil. Pelaksanaan proses pembelajaran pada kelas bisa dilihat dari dua variable diantaranya kondisi pembelajaran yang lagi berlangsung serta hasil yang diharapkan dalam proses pembelajaran (degeng dalam Zusmelia, 2017).

Luaran sebagai calon pendidik dari FPMIPA juga diharapkan memiliki kreatifitas dalam menyampaikan materi sekolah, serta memiliki inovasi dalam menyampaikan pembelajaran di dalam kelas untuk membantu menghilangkan rasa bosan pada siswa sehingga menjadikan pembelajaran lebih menyenangkan, hal tersebut untuk mewujudkan kualitas pembelajaran yang baik.sehingga luaran calon pendidik yang dihasilkan oleh FPMIPA memiliki mutu dan kualitas, dari mutu dan kualitas calon pendidik salah satunya juga disebabkan dari kualitas penerimaan mahasiswa baru yang baik pula.

\section{SIMPULAN}

Kesimpulan yang diperoleh dari hasil analisa bahwamahasiswa baru FPMIPA yang mempunyai minat memilih program studi pendidikan biologi juga memiliki kemampuan dasar matematika hal tersebut merupakan upaya peningkatan kualitas penerimaan mahasiswa baru pada FPMIPA. Saran penelitian ini bahwa FPMIPA harus memiliki 
luaran calon pendidik yang professional, khususnya program studi pendidikan matematika memiliki luaran pendidik yang professional juga menyenangkan serta kreatif dan inovatif dalam menyampaikan materi matematika sekolah, agar tercipta pandangan masayarakat bahwa belajar matematika juga menyenangkan seperti belajar yang lainnya.

\section{UCAPAN TERIMA KASIH}

Ucapan terima kasih kepada pimpinan FPMIPA yang memberikan kesempatan kepada kami untuk menganalisa kemampuan dasar matematika pada mahasiswa baru yang berada di FPMIPA, serta memberikan ijin untuk menggunakan data mahasiswa dalam penelitian ini.

\section{DAFTAR PUSTAKA}

Amir, Z. (2013). Perspektif Gender Dalam Pembelajaran Matematika. Marwah: Jurnal Perempuan agama dan jender, 1228.httpsdxdoi.org10.24014marwah.v12i1.511

Anita, I.W.(2014). Pengaruh Kecemasan Matematika (MathematicsAnxiety) Terhadap Kemampuan Koneksi Matematis siswa SMP. Jurnal Ilmiah Program Studi Matematika STKIP Siliwangi Bandung, 3(1), 125132.https:// doi.org10.22460infinity.v3i1.p125-132

Dewanti, S. D. (2012). Analisis Kesiapan Mahasiswa Program Studi Pendidikan Matematika Sebagai Calon Pendidik Profesional. Prosiding Konferensi Nasional Penelitian Matematika dan Pembelajaran, 17-27

Firmansyah, M. A. (2017). Peran Kemampuan Awal Matematika dan Belief Matematika Terhadap Hasil Belajar.Prima: Jurnal Pendidikan Matematika, 1(1), 55-68. https://jurnal.umt.ac.idindex.phpprimaarticleview255164.pdf

Irvaniyah, I. \& Akbar, R. O. (2014).Analisis Kecerdasan Logis Matematis dan Kecerdasan Linguistik Siswa Berdasarkan Jenis Kelamin. Jurnal EduMa, 3(1), 138-159. http://syekhnurjati.ac.idjurnalindex.phpedumaarticleview188

Sandewita, N.(2015).Pelaksanaan Pembelajaran Matematika Oleh Guru Kelas Terhadap Siswa Autism. Jurnal Ilmiah Pendidikan Khusus,4(3), 319-333. http:// ejournal.unp.ac.id/index.php/jepekhu

Siregar, N.R. (2017). Persepsi Siswa Pada Pelajaran Matematika : Studi Pendahuluan Pada Siswa Yang Menyenangi Game. Prosiding Temu Ilmiah X Ikatan Psikologi Perkembangan Indonesia, 224-232.

Suherman.(2015). Kreativitas Siswa Dalam Memecahkan Masalah Matematika Materi Pola Bilangan Dengan Pendekatan Matematika Realistik. Al-Jabar:Jurnal Pendidikan Matematika, 6(1), 81-90. https://doi.org10.24042ajpm.v67i1.57

Widyawati, S. (2016).Pengaruh Gaya Belajar Terhadap Prestasi Belajar Mahasiswa Program Studi Pendidikan Matematika (IAIM NU) Metro. Al-Jabar:Jurnal Pendidikan Matematika, 7(1), 107-114. https:/ / doi.org10.24042ajpm.v7i1.135

Zusmelia, \& Irwan, \& Ramadoni, \& Anggela, R. V. (2017).Tantangan Profesionalisme Guru Pada Pembelajaran Matematika Melalui \$C's Ditinjau Dari Perspektif sosiologi. Prosiding Seminar Nasional STKIP PGRI Sumatera Barat, 3(1), 28-45. http://repo.stkip-pgri-sumbar.ac.iddeprint32211Zusmelia.pdf 